\title{
ЗАБЕЗПЕЧЕННЯ ТОЧНОСТІ ОПИСУ ХАРАКТЕРИСТИК ГРУП ФОТОПЕРЕТВОРЮВАЧІВ І ФОТОЕЛЕКТРИЧНИХ БАТАРЕЙ НА ОСНОВІ ЦІЛЬОВИХ ЕКСПЕРИМЕНТІВ НА КОМПЛЕКСНОМУ ОБЛАДНАННІ
}

\author{
К.В. Безручко ${ }^{1}$, докт. техн. наук, проф., Л.І. Книш ${ }^{2}$, докт. техн. наук, проф., С.В. Сінченко ${ }^{1}$, канд. техн. наук \\ ${ }^{1}$ Національний аерокосмічний університет ім. М.Є. Жуковського «Харківський авіаційний інститут», \\ 61070 , вул. Чкалова, 17, м. Харків, Україна. \\ ${ }^{2}$ Дніпровській національний університет імені Олеся Гончара, \\ 49010, пр. Гагаріна, 72, м. Дніпро, Україна.
}

\begin{abstract}
Підвищення ефективності перетворення енергї сонячного випромінювання в електроенергію сонячними елементами є основним завданням сонячної енергетики. А сучасний інтерес до проектування і експлуатації фотоелектричних батарей на основі сонячних елементів призводить до оиінювання їх основних експлуатаційних характеристик. Для контролю якості та ефективності сонячного елемента на виробництві або в лабораторних умовах необхідно точно виміряти його вольтамперну характеристику, яка є основним джерелом інформації про параметри та характеристики сонячного елемента, таких як коефіцієнт корисної дї, максимальну потужність, струм короткого замикання, напругу холостого ходу, струм $i$ напругу при максимальній потужності, коефіцієнт форми тощо. При проектуванні фотоелектричних батарей великих площ, наземного або космічного застосування, виникають труднощі у визначенні різних втрат, таких як комутація фотоелементів, їх не ідентичність, нерівномірності температури і освітленості фотоелектричних батарей. Зазвичай иі втрати враховують введенням у математичну модель різних коефіцієнтів. Експериментальні дослідження в напрямку більш точного визначення всіляких втрат в фотоелектричних батареях призводять до не окупності та ускладнення проведення таких експериментальних досліджень. Для проектування і випробування фотоелектричних батарей великих площчин авторами пропонується підхід, який оснований на побудові вольт-амперних характеристик фотоелектричних батарей. Запропонований підхід дозволяє з визначенням воль-амперної характеристики окремого сонячного елемента або груп фотоелектричних перетворювачів, получити моделі при різних рівнях освітленості і температури з характерними параметрами фотоелектричних батарей будь-якої площі. Авторами проведено експериментальне підтвердження запропонованої методики, а також порівняння з іншими експериментальними дослідженнями. В методиці визначені перехідні коефіцієнти математичної моделі, а також розписані особливості застосування запропонованого підходу. Бібл.6, рис. 2.
\end{abstract}

Ключові слова: сонячний фотоелектричний елемент, сонячна фотоелектрична батарея, вольт-алперна характеристика, потужність, струм короткого замикання, напруга холостого ходу, освітленість.

\section{PROVIDING OF THE DESCRIPTION ACCURACY OF THE CHARACTERISTICS FOR GROUPS OF SOLAR PHOTOVOLTAIC CELL AND SOLAR ARRAY BASED ON TARGET EXPERIMENTS ON THE COMPLEX EQUIPMENT}

\author{
K. Bezruchko ${ }^{1}$, doctor of technical sciences, professor, L. Knysh ${ }^{2}$, doctor of technical sciences, professor, S. Sinchenko ${ }^{1}$, Ph.D. \\ ${ }^{1}$ National Aerospace University «Kharkiv Aviation Institute», \\ 61070, 17 Chkalov St., Kharkov, Ukraine. \\ ${ }^{2}$ Oles Honchar Dnipro National University, \\ 49000, 72 Gagarin Av., Dnipro, Ukraine.
}

Improving the efficiency of converting solar radiation energy into electricity by solar cells is the main task of solar energy. And the modern interest in the design and operation of photovoltaic batteries based on solar cells leads to the evaluation of their main performance characteristics. To control the quality and efficiency of a solar cell in production or in the laboratory, it is necessary to accurately measure its volt-ampere characteristic, which is the main source of information about the parameters and characteristics of the solar cell, such as efficiency, maximum power, short circuit current, no-load voltage, current and voltage at maximum power, form factor, etc. When designing photovoltaic batteries of large areas, ground or space applications, there are difficulties in determining the various losses, such as switching of photocells, their non-identity, uneven temperature and illumination of photovoltaic batteries. Usually these losses are taken into account by introducing various coefficients into the mathematical model. Experimental studies in the direction of more accurate determination of all kinds of losses in photovoltaic batteries lead to non-payback and complicate the conduct of such experimental studies. For the design and testing of large-area photovoltaic batteries, the authors propose an approach that is based on the construction of volt-ampere characteristics of photovoltaic batteries. The proposed approach allows to determine the free-ampere characteristics of an individual solar cell or groups of photovoltaic converters, to obtain models at different levels of illumination and temperature with the characteristic parameters of photovoltaic batteries of any area. The authors conducted an experimental confirmation of the proposed method, as well as a comparison with other experimental studies. The method identifies the transition coefficients of the mathematical model, as well as the features of the proposed approach. Bibl. 6 , Fig. 2.

Keywords: solar photovoltaic cell, solar array, current-voltage characteristic, power, short circuit current, open circuit voltage, illumination. 


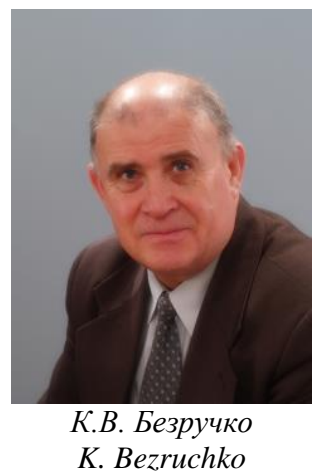

Відомості про автора: професор кафедри космічної техніки та нетрадиційних джерел енергії Національного аерокосмічного університету ім. М.Є. Жуковського «Харківський авіаційний інститут», доктор технічних наук, професор.

Освіта: Харківський авіаційний інститут. Спеціальність «Двигуни літальних апаратів».

Наукова сфера: математичне і фізичне моделювання систем електрозабезпечення космічного і наземного застосування.

Публікації: більше 130 наукових праць 3 них 3 містяться в наукометричній базі Scopus.

ORCID: 0000-0002-9092-2732

Контакти: тел./факс: +38057788-40-65

e-mail: k.bezruchko@khai.edu

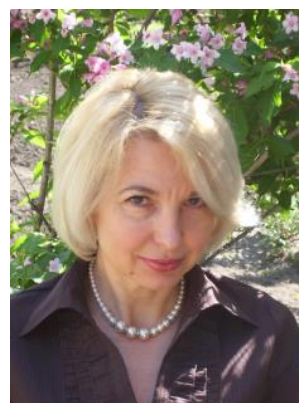

Л.І. Книш

L. Knysh

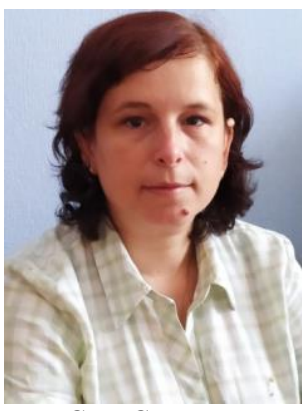

C.B. Сінченко

S. Sinchenko
Відомості про автора: Завідувач кафедри аерогідромеханіки та енергомасопереносу Дніпровського національного університету імені Олеся Гончара, доктор технічних наук, професор.

Освіта: Дніпропетровський державний університет.Спеціальність «Гідроаеродинаміка».

Наукова сфера: фахівець в галузі математичного та комп'ютерного моделювання процесів аерогідродинаміки та теплообміну.

Публікації: більш ніж 100.

ORCID: 0000-0003-3525-4804

Контакти: тел./факс: +38 0990034310 e-mail: 1knysh@ukr.net

Відомості про автора: Завідуюча кафедрою космічної техніки та нетрадиційних джерел енергії Національного аерокосмічного університету ім. М.С. Жуковського «Харківський авіаційний інститут», кандидат технічних наук. Освіта: Національний аерокосмічний університет ім. М.Є. Жуковського «Харківський авіаційний інститут». Спеціальність «Двигуни та енергетичні установки літальних апаратів». Наукова сфера: математичне моделювання і експериментальні випробування систем електрозабезпечення космічного і наземного застосування.

Публікації: більше 20 наукових праць.

ORCID: 0000-0002-3331-6867

Контакти: тел./факс: +38057788-44-02

e-mail: s.sinchenko@khai.edu
Author information: professor, Department of Space Technology and Alternative Energy Sources, National Aerospace University «Kharkov Aviation Institute», doctor of technical sciences, professor.

Education: Kharkov Aviation Institute. Specialty aircraft engines.

Research area: mathematical and physical modeling of power supply systems for space and ground applications.

Publications: more than 130 scientific works of which 3 are in the scientometric base Scopus.

ORCID: 0000-0002-9092-2732

Contacts: tel./fax: +38057788-40-65

e-mail: k.bezruchko@khai.edu

Author information: Chair of Department of Aehydromechanics and Energy and Mass Transfer of Oles Gonchar Dnipro National University, doctor of technical science, professor.

Education: Dnipropetrovsk State University, Specialty Hydroaerodynamics.

Research area: expert in the field of mathematical and computational modeling of fluid dynamics and heat and mass transfer processes.

Publications: over 100

ORCID: 0000-0003-3525-4804

Contacts: tel./fax: +380990034310

e-mail: 1knysh@ukr.net

Author information: Head of the Department of Space Technology and Renewable Energy, National Aerospace University «Kharkov Aviation Institute», candidate of technical sciences.

Education: National Aerospace University. Zhukovsky ME «Kharkov Aviation Institute». Specialty «Aircraft engines and power plants».

Research area: mathematical modeling and experimental tests of power supply systems for space and ground applications.

Publications: over 20

ORCID: 0000-0002-3331-6867

Contacts: tel./fax: +38 057788-44-02

e-mail: s.sinchenko@khai.edu

$N_{\max }^{\Gamma}$ - максимальна потужність групи фотоперетворювачів;

$E_{Б \Phi}$ - освітленість батареї фотоелектричної;

$T_{Б \Phi}$ - температура батареї фотоелектричної;

BAX - воль-амперна характеристика;

БФ - батарея фотоперетворювачів;

ФП - фотоперетворювач;

$\mathrm{GaAs}$-галій-арсенід;

Si ФП - кремнієвий фотоперетворювач. 
Вступ. Сьогодні у світі відмічається тенденція вирішення екологічних проблем за допомогою застосування альтернативних джерел енергії. Сонце - важливе відновлюване та екологічно чисте джерело енергії. Сонячну енергію можна перетворювати в електричну за допомогою фотоелектричних перетворювачів $(Ф П), \quad$ які компонуються у батареї фотоелектричні (БФ), які, як правило, називають сонячними панелями. Такі джерела енергії $\epsilon$ безпечними для довкілля, та відносно надійними 3 енергетичної точки зору. Тому спостерігається стійкий інтерес споживачів щодо використання сонячних панелей, який стимулює покращення технології їх виробництва, удосконалення конструкції та особливостей комутації. Збільшення інтересу до фотоелектричних перетворювачів призводить до інтенсивних наукових досліджень в цій галузі та робіт по модернізації та розробки нових зразків з новими матеріалами. Для контролю якості та ефективності сонячного елемента на виробництві або в лабораторних умовах необхідно точно виміряти його вольт-амперну характеристику (BAX), яка є основним джерелом інформації про параметри та характеристика сонячного елемента (коефіцієнт корисної дії, максимальну потужність, струм короткого замикання, напругу холостого ходу, струм i напругу при максимальній потужності, коефіцієнт форми тощо). На них впливають оптичні, електрофізичні властивості напівпровідника. Лише детальний аналіз дозволяє визначити ту чи іншу причину недостатнього рівня коефіцієнта корисної дії певного зразка сонячного елемента.

Саме цим обумовлена актуальність роботи, в якій пропонується новий комплексний підхід до експериментальних досліджень сонячних панелей, що базується на використанні математичної моделі опису ВАХ групи БФ для різних рівнів освітленостей i температур, яку можна використовувати при описі ВАХ БФ будьякої площі спроектованих БФ. Запропонована методика дозволяє забезпечити найліпшу точність опису характеристик груп фотоперетворювачів і фотоелектричних батарей. Цей підхід може бути застосований до панелей 3 різними типами ФП, різної потужності та площі. Використання запропонованої методики приведе до підвищення загальної ефективності показників сонячних батарей, збільшення їх надійності та зниженню вартості.

Постановка задачі. Побудова вольтамперної характеристики сонячної панелі на основі теоретичного або експериментально обгрунтованого опису $\mathrm{BAX}$ окремого фотоелектричного перетворювача стало певною мірою традиційним. Однак при проектуванні БФ великих площ виникають труднощі у встановленні втрат, які мають різну природу. Серед них основними $є$ комутація фотоелементів, їх неідентичність, нерівномірності температури i освітленості БФ і т.п. [1-3]. Зазвичай ці втрати враховують введенням у модель різних коефіцієнтів, як зазначено в роботі [3-6]. Детальні ж експериментальні дослідження в напрямку більш точного визначення всіляких втрат в БФ призводять до не окупності та ускладнення проведених робіт.

У цій роботі авторами пропонується інший підхід до побудови ВАХ БФ. Суть його полягає в тому, що будується опис експериментальних BAX не поодинокого ФП, а групи ФП, щодо великої площі. Це виконується за допомогою методу регресійного аналізу шляхом обробки результатів експериментів на зазначених групах ФП в широкому діапазоні рівнів освітленостей і температур. В отриманій таким чином регресійній математичної моделі для ВАХ групи БФ перераховані вище схемні втрати враховуються інтегрально. Відносячи параметри цієї моделі до характерних параметрів або площі групи ФП, отримаємо математичну модель, яку можна використовувати при описі ВАХ БФ будьякої площі при різних рівнях освітленості і температури. Таким чином, схемні втрати груп ФП враховуються «масштабуванням» на всій поверхні проектованої БФ.

Дослідження характеристик груп ФП. У літературних джерелах замало інформації щодо експериментальних досліджень ВАХ груп фотоелементів відносно великій площі в необхідному вигляді i в необхідному для побудови математичної моделі обсязі. Тому в рамках інформаційного забезпечення математичної моделі БФ проведені власні цільові експерименти на групах кремнієвих фотоелементів [1].

Для експериментів авторами сформовано шістнадцять груп Si ФП (розробки АТ «НВП «Квант»), кожна з яких має активну площа 0.0403 $\mathrm{M}^{2}$ і комутується 3 трьома-чотирма стандартними групами для обліку втрат від цього виду комутації. Облік втрат від не ідентичності ФП в групах (крім технологічних відмінностей) досягається за рахунок наявності в групах фотоелементів різних розмірів (20х27; 20х24;

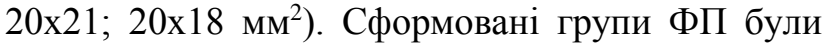
розміщені на одній з панелей, модифікованої під стендовий варіант, а між групами рівномірно по площі встановлені датчики температури i освітленості. 
Метою експериментального дослідження груп ФП 3 кремнію на експериментальному обладнанні було одержання залежностей характеристик параметрів $I_{K 3}^{\Gamma}, U_{X X}^{\Gamma}, I_{O П T}^{\Gamma}, U_{O П T}^{\Gamma}$ від освітленості і температури (при різних поєднаннях цих двох факторів). Для цього була розроблена спеціальна експериментальна програма, яка мінімізує сумарний час експерименту. Два фактори - освітленість і температура - фіксувалися відповідно на п'яти рівнях для груп $\mathrm{Si} Ф П$.

Значення $I_{\text {OПт }}^{\Gamma}$ і $U_{\text {OПт }}^{\Gamma}$ безпосередньо не вимірювалися, але в області оптимального режиму реєструвалися точки ВАX 3 меншим кроком. Потім визначення $I_{\text {OПT }}^{\Gamma}$ і $U_{\text {OПT }}^{\Gamma}$ проводилось розрахунковим шляхом при обробці експериментів з умови досягнення $N_{\max }^{\Gamma}$.

Реєстрація струму і напруги в кожній точці ВАХ супроводжувалася реєстрацією інформації трьох найближчих до цієї групи спарених датчиків температури і освітленості. В результаті отримані експериментальні залежності (1):

$$
\begin{gathered}
I_{K 3}^{\Gamma}=f\left(E_{Б \Phi}, T_{Б \Phi}\right), \\
U_{X X}^{\Gamma}=f\left(E_{Б \Phi}, T_{Б \Phi}\right), \\
I_{O \Pi T}^{\Gamma}=f\left(E_{Б \Phi}, T_{Б \Phi}\right), \\
U_{O I T}^{\Gamma}=f\left(E_{Б \Phi}, T_{Б \Phi}\right),
\end{gathered}
$$

Прямі експерименти на панелі БФ. Прямі експериментальні дослідження ВАХ панелей БФ необхідні:

- для порівняння математичних описів характеристик БФ на базі експериментальних досліджень груп ФП і встановлення адекватності моделі і реальної панелі;

- для відпрацювання експериментальних програм дослідження натурних БФ великих площ (як i iнших агрегатів системи електрозабезпечення), iз застосуванням автоматизованої інформаційно-керуючої системи моделюючого стенду БФ [1-2].

Для експериментів використовувалася панель на базі $\mathrm{Si}$, що має активну площа

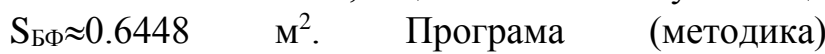
експерименту побудована 3 розрахунку максимальної автоматизації експерименту 3 застосування комп'ютера i програмного забезпечення.
Задані значення освітленості $\mathrm{E}_{\text {БФ }}=$ $\left(500 \ldots 1400 \mathrm{BT} / \mathrm{M}^{2}\right)$ забезпечуються попередньою установкою досліджуваної панелі БФ на заданій відстані від освітлювача. Всі наступні операції здійснюються від комп'ютера, який регулює температуру охолодження повітря в камері БФ, стабілізуючи заданий рівень температури панелі БФ $\quad\left(\begin{array}{llll}10 & \ldots & 70 & { }^{\circ} \mathrm{C}\end{array}\right)$, автоматично змінює навантаження панелі БФ, забезпечуючи реєстрацію точок ВАХ від $U_{x x}$ до $I_{\kappa з}$ із заданою дискретністю, проводить повторну реєстрацію (до 10 раз) параметрів і в підсумку видає на друк експериментальну інформацію: $U_{Б \Phi}, I_{Б \Phi}, N_{O П T}^{\bar{~}}, \frac{I_{O П T}}{I_{K 3}}, \frac{U_{O П T}}{U_{X X}}$ в залежності від $T_{c p}^{5 \Phi}$ i $E_{c p}^{5 \Phi} \quad$ (при цьому здійснюється також статистична обробка експериментальних даних і оцінюється похибка експерименту).

Результати експериментального дослідження характеристик розглянутої панелі БФ (на основі Si ФП) представлені на рис. 1. Похибка забезпечення заданих рівнів $\mathrm{E}_{\text {БФ }}$ і $\mathrm{T}_{\text {БФ }}$ не перевищує 5\% (при нерівномірності на площі панелі температури менше $4 \%$ i освітленості менше 1\%). Середньоквадратичне відхилення вимірювань складають: по струму $-5.32 \times 10^{-2}$, по напрузі $-6.83 \times 10^{-2}$.

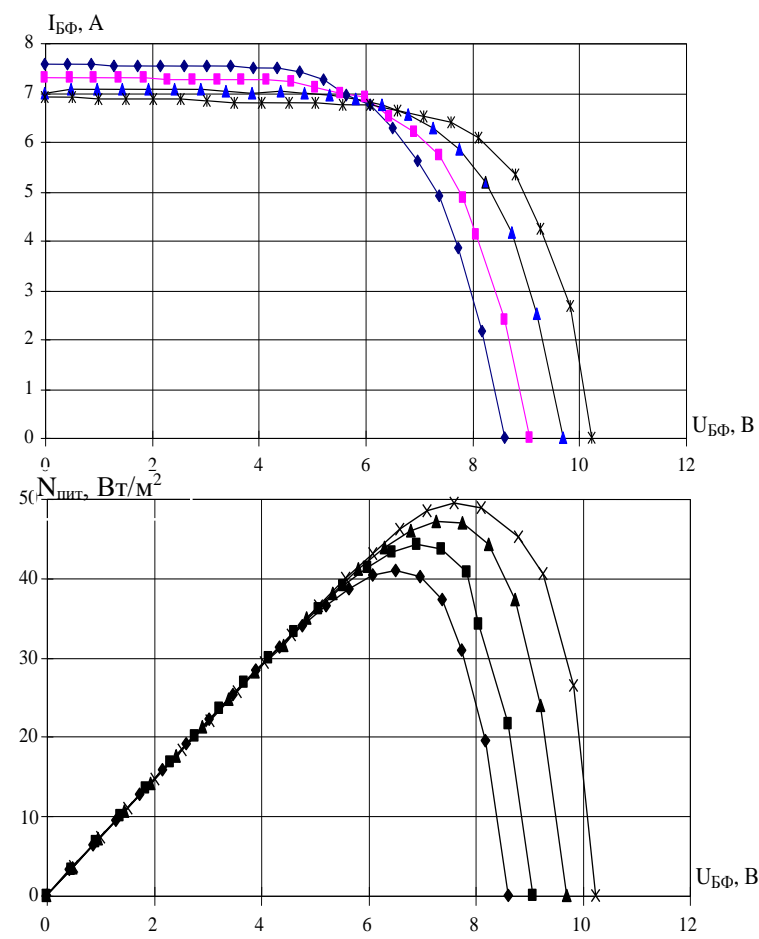

Рис. 1. Вольт-амперні і потужностні характеристики

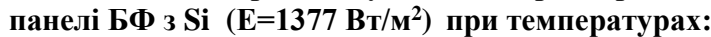
$\rightarrow \mathrm{T}=70{ }^{\circ} \mathrm{C} ; \quad-\mathrm{T}=60^{\circ} \mathrm{C} ; \quad \leftarrow \mathrm{T}=50^{\circ} \mathrm{C} ; \quad$ * $\mathrm{T}=40^{\circ} \mathrm{C}$

Fig. 1. Volt-ampere and power characteristics of the panel silicon-based $\left(E=1377 \mathrm{~W} / \mathrm{m}^{2}\right)$ at different temperatures $\rightarrow \mathrm{T}=70{ }^{\circ} \mathrm{C} ;-\mathrm{T}=60{ }^{\circ} \mathrm{C} ; \quad \leftarrow \mathrm{T}=50^{\circ} \mathrm{C} ; \quad$ * $\mathrm{T}=40{ }^{\circ} \mathrm{C}$ 
Проведено порівняння характеристик панелі БФ, отриманих прямим експериментом, а також 3 розрахунком по математичної моделі панелі БФ.
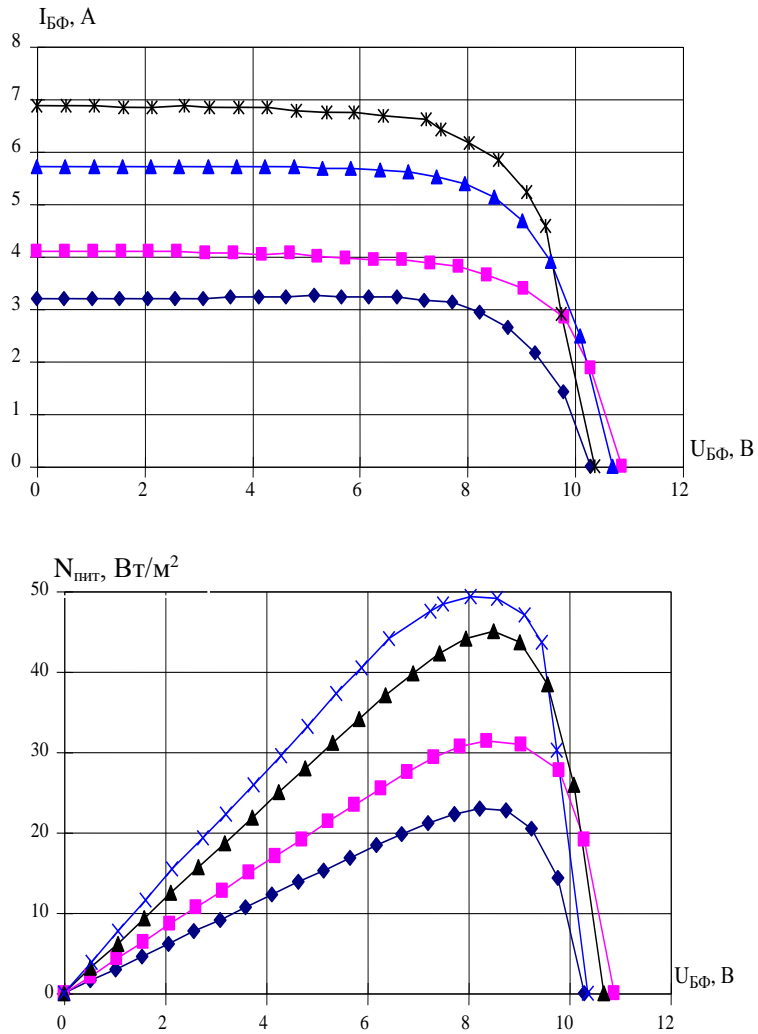

Рис. 2. Вольт-амперні і потужностні характеристики панелі БФ з $\mathrm{Si}\left(\mathrm{T}=2^{\circ} \mathrm{C}\right)$ при різних рівнях освітленості: $+\mathrm{E}=570 \mathrm{BT} / \mathrm{M}^{2} ;-\mathrm{I}=782 \mathrm{BT} / \mathrm{M}^{2} ;+\mathrm{E}=1125 \mathrm{BT} / \mathrm{M}^{2} ; * \mathrm{E}=1377 \mathrm{BT} / \mathrm{M}^{2}$

Fig. 2. Volt-ampere and power characteristics the panel silicon-based $\left(\mathrm{T}=\mathbf{2 5}^{\circ} \mathrm{C}\right)$ at different light levels:

$+\mathrm{E}=570 \mathrm{BT} / \mathrm{M}^{2} ;-\mathrm{E}=782 \mathrm{BT} / \mathrm{M}^{2} ;+\mathrm{E}=1125 \mathrm{BT} / \mathrm{M}^{2} ; * \mathrm{E}=1377 \mathrm{BT} / \mathrm{M}^{2}$

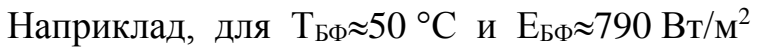
визначені:

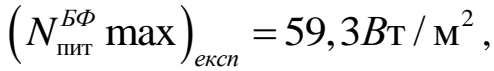

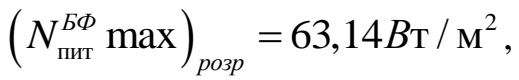

що свідчить про цілком прийнятне узгодження результатів.

Побудова виразу ВАХ групи ФП. В отриманій таким чином регресійній математичній моделі ВАХ групи ФП схемні втрати (комутаційні, від не ідентичності ФП і ін.) враховуються інтегрально. Математична модель ВАХ БФ будується на основі математичних моделей груп ФП. Такий підхід дає можливість отримати досить точну модель БФ, що дозволяє описати ВАХ БФ не тільки в нормальному режимі ï роботи, але і при частковому іï затемнені або нерівномірному полі температур по поверхні.

Конкретизуючи залежності для $I_{\Gamma}$, вибираємо в якості вихідного виразу

$I_{\Gamma}=I_{K 3}-k_{1} \cdot \exp \left(k_{2} \cdot\left(U-U_{X X}\right)\right)$,

де $k_{1}, k_{2}$ - коефіцієнти, що визначаються з умови проходження ВАX через характерні точки: короткого замикання, холостого ходу i оптимальну.

Умови проходження ВАХ через три точки записуються у вигляді:

$$
\begin{array}{ll}
\mathrm{I}_{\mathrm{r}}=\mathrm{I}_{\text {кз }} & \text { при } \mathrm{U}=0 ; \\
\mathrm{I}_{\mathrm{\Gamma}}=0 & \text { при } \mathrm{U}=\mathrm{U}_{\text {хx }} ; \\
\mathrm{I}_{\mathrm{r}}=\mathrm{I}_{\text {опт }} & \text { при } \mathrm{U}=\mathrm{U}_{\text {опт. }}
\end{array}
$$

В силу перевизначення системи коефіцієнт $k_{l}$ може бути обчислений з виразу:

$$
k_{1}=I_{K 3} \cdot\left(\frac{U}{U_{X X}}\right),
$$

яке задовольняє двом умовам - (3), (4).

За умов (2-5) визначаємо

$$
k_{2}=\ln \left[\left(I_{K 3}-I_{\text {ОПT }}\right) / k_{1}\right] /\left(U_{\text {OПT }}-U_{X X}\right) .
$$

Підставивши формули (6) і (7) в рівняння (2), отримаємо математичний опис ВАХ групи ФП:

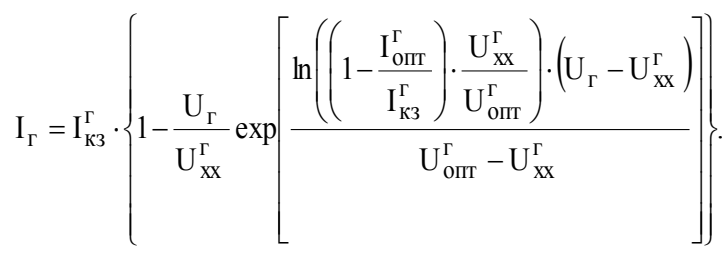

Вхідні параметри у виразі (8) залежать від освітленості $E$ і температури $T$. Для знаходження цих залежностей прийнята поліноміальна модель виду:

$$
\left.\begin{array}{l}
\mathrm{I}_{\mathrm{K} 3}^{\Gamma}=\alpha+\beta \mathrm{T}+(\delta \mathrm{T}+\gamma) \cdot \mathrm{E} \\
\mathrm{U}_{\mathrm{xx}}^{\Gamma}=\alpha_{1}+\beta_{1} \mathrm{~T}+\left(\delta_{1} \mathrm{~T}+\gamma_{1}\right) \cdot \mathrm{E} ; \\
\mathrm{I}_{\mathrm{O \Pi T}}^{\Gamma}=\alpha_{2}+\beta_{2} \mathrm{~T}+\left(\delta_{2} \mathrm{~T}+\gamma_{2}\right) \cdot \mathrm{E} ; \\
\mathrm{U}_{\text {опт }}^{\Gamma}=\alpha_{3}+\beta_{3} \mathrm{~T}+\left(\delta_{3} \mathrm{~T}+\gamma_{3}\right) \cdot \mathrm{E} .
\end{array}\right\}
$$

Коефіцієнти $\alpha-\alpha_{3}, \beta-\beta_{3}, \gamma-\gamma_{3}$, визначалися методом регресійного аналізу при обробці даних цільових експериментів на групах ФП $3 \mathrm{Si}$. Аналогічно будуються характеристики груп ФП i 
БФ в цілому на основі $\mathrm{GaAs}$, що підтверджено проведеними експериментальними дослідженнями у відділенні енергетики кафедри космічної техніки та нетрадиційних джерел енергії.

Побудова ВАХ панелі БФ. Параметри характерних точок ВАХ БФ (при реалізації другого шляху отримання ВАХ БФ) доцільно визначати 3 використанням відповідних параметрів груп ФП. Припускаючи для цього, що форма ВАХ БФ якісно повторює форму ВАХ групи ФП при будь-яких значеннях $E$ i $T$ розглянутого діапазону, запишемо:

$$
\begin{aligned}
& \mathrm{I}_{\mathrm{K} 3}^{\mathrm{L} \Phi}=\mathrm{k}_{\mathrm{I}_{\mathrm{K} 3}} \cdot \mathrm{I}_{\mathrm{K} 3}^{\mathrm{\Gamma}}\left(\mathrm{E}_{\mathrm{Б} \Phi}, \mathrm{T}_{\mathrm{Б} \Phi}\right) \text {; } \\
& \mathrm{U}_{\mathrm{Xx}}^{\mathrm{L} \Phi}=\mathrm{k}_{\mathrm{U}_{\mathrm{xx}}} \cdot \mathrm{U}_{\mathrm{xx}}^{\mathrm{\Gamma}}\left(\mathrm{E}_{\mathrm{Б} \Phi}, \mathrm{T}_{\mathrm{Б} \Phi}\right) \text {; } \\
& \mathrm{I}_{\text {OПт }}^{\text {БФ }}=\mathrm{k}_{\mathrm{I}_{\text {OПт }}} \cdot \mathrm{I}_{\text {ОПт }}^{\mathrm{\Gamma}}\left(\mathrm{E}_{\text {БФ }}, \mathrm{T}_{\text {БФ }}\right) \text {; } \\
& \mathrm{U}_{\text {оाт }}^{\mathrm{Б} \Phi}=\mathrm{k}_{\mathrm{U}_{\text {ОПт }}} \cdot \mathrm{U}_{\text {оाт }}^{\mathrm{\Gamma}}\left(\mathrm{E}_{\text {БФ }}, \mathrm{T}_{\text {БФ }}\right) \text {. }
\end{aligned}
$$

Масштабні коефіцієнти $k_{I_{\kappa з}}, k_{U_{x x}}, k_{I_{\text {onm }}}$, $k_{U_{\text {onm }}}$ можна розрахувати наступним чином. Використовуючи усереднену питому потужність груп ФП (Nг / Sг) і застосовуючи при переході до

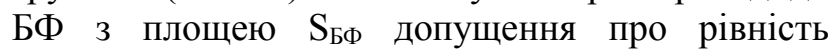
питомих потужностей БФ і груп ФП в оптимальних точках їх $\mathrm{BAX}\left(\frac{N_{\max }^{S \Phi}}{S_{5 \Phi}^{\prime}}\right) \approx\left(\frac{N_{\max }^{\Gamma}}{S_{\Gamma}}\right)$, тоді отримаємо

$$
N_{\max }^{\mathrm{L \Phi}} \approx \frac{N_{\max }^{\Gamma}}{S_{\Gamma}} \cdot S_{\text {БФ }}^{\prime},
$$

де $S_{Б \Phi}^{\prime}=k_{\text {дегр }} \cdot k_{\text {зап }} \cdot S_{Б \Phi}$,

$k_{\text {дегр }}-$ коефіцієнт, що враховує деградацію параметрів БФ; $k_{3 a n}$ - коефіцієнт, що характеризує повноту заповнення ФП площі БФ і визначається за конкретно виконаним БФ (як приклад, для перспективних БФ космічного призначення $k_{\text {заn }}=$ $0.91 \ldots . . .0 .96)$.

Перетворюючи вираз (11), запишемо:

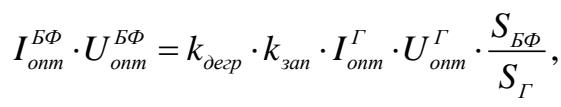

або

$$
k_{I_{\text {onn }}}^{0}=\frac{k_{\text {дегp }} \cdot k_{\text {зап }}}{k_{U_{\text {onn }}}^{0}} \cdot \frac{S_{5 \Phi}}{S_{\Gamma}},
$$

де масштабні коефіцієнти в оптимальній точці ВАХ БФ взяті при умовах експлуатації БФ $\left(E_{0}^{5 \Phi}=1360 \mathrm{BT} / \mathrm{M}^{2}, T_{0}^{5 \Phi}=60^{\circ} \mathrm{C}\right)$;

$$
\begin{gathered}
k_{I_{\text {onm }}}^{0}=I_{\text {onm }}^{\text {EФ }} / I_{\text {onm }}^{\Gamma} ; \\
k_{U_{\text {onm }}}^{0}=U_{\text {onm }}^{\text {On }} / U_{\text {onm }}^{\Gamma} .
\end{gathered}
$$

У діапазоні температур $10 \quad \ldots \quad 70^{\circ} \mathrm{C} \quad \mathrm{i}$ освітленості $550 \ldots 1360$ Вт/м² для шістнадцяти груп кремнієвих фотоелементів залишкова дисперсія опису склала 0,00757, а середньоквадратичне відхилення 0,087. Якість опису BAX можна оцінити візуально за рис. 1. Для прикладу тут описано точки ВАХ однієї 3 груп, а середня відносна похибка для всіх груп 3 Si ФП становить 3,3\%.

Якість отриманих виразів (9) і (10) перевірялась також шляхом порівняння за дослідженнями інших організацій, та експериментах, проведених на групах ФП 3 GaAs. Так, наприклад, основні параметри тих же груп ФП з GaAs за експериментальними даними мають значення:

при $\mathrm{E}=1360 \mathrm{BT} / \mathrm{M}^{2} ; \mathrm{T}=40^{\circ} \mathrm{C}$ та $\mathrm{S}_{\mathrm{r}}=9,3 \cdot 10^{-3} \mathrm{~m}^{2}$; $\mathrm{U}_{\mathrm{xx}}{ }^{\mathrm{r}}=3,6 \mathrm{~B} ; \quad \mathrm{I}_{\mathrm{K} 3}{ }^{\mathrm{r}}=0,527 \mathrm{~A} ; \quad \mathrm{U}_{\mathrm{opt}}{ }^{\mathrm{r}}=2,8 \mathrm{~B} ; \quad \mathrm{I}_{\mathrm{opt}}{ }^{\mathrm{r}}=$ $0,4749 \mathrm{~A} ; \mathrm{N}_{\text {пит }}{ }^{\mathrm{r}}=143,0003 \mathrm{BT} / \mathrm{M}^{2}$.

Перехід від ВАХ груп ФП до ВАХ БФ можна здійснити двома шляхами:

1) Прямим обчисленням $\mathrm{I}_{\mathrm{Б} \Phi}=\mathrm{m}_{\Gamma} \cdot \mathrm{I}_{\Gamma}$ i $\mathrm{U}_{\mathrm{Б} \Phi}=\mathrm{n}_{\Gamma} \mathrm{U}_{\Gamma}$, що в значній мірі ідеалізує схему комутації груп ФП в панелі великої площі; тут $\mathrm{I}_{\Gamma}$ визначається по залежності (8);

2) з використанням виразу (8), розглядаючи БФ як граничний випадок групи ФП; при цьому у виразі (8) $\mathrm{I}_{\Gamma}$ і $\mathrm{U}_{\Gamma}$ замінюються відповідно на $\mathrm{I}_{Б}$ i $\mathrm{i}$ $\mathrm{U}_{\mathrm{Б} \Phi}$, a $\mathrm{I}_{\mathrm{K} 3}{ }^{\mathrm{r}}, \mathrm{U}_{\mathrm{xx}}{ }^{\mathrm{r}}, \mathrm{I}_{\mathrm{opt}}{ }^{\mathrm{r}}, \mathrm{U}_{\mathrm{opt}}{ }^{\mathrm{r}}$ замінюються на

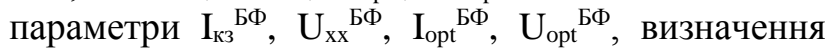
яких прямим експериментом викликає суттєві труднощі.

У той же час використання виразу (8) для розрахунку ВАХ БФ дозволяє врахувати схемні втрати потужності БФ (комутаційні, від не ідентичності ФП, від температурних нерівномірностей, часткового затінення і т.д.) i не залежить від реалізації тієї чи іншої схеми комутації груп ФП в БФ. 3 іншого боку, приймаючи напругу в робочій точці ВАХ БФ $\mathrm{U}_{\text {БФ }} \approx \mathrm{U}_{\text {орt }}^{\text {БФ }}$ i враховуючи, що $\mathrm{U}_{\text {БФ }}=\mathrm{U}_{\mathrm{H}}+\Delta \mathrm{U}_{\text {БФ }}$ (при наявності в складі енергоустановки апаратури регулювання, яка під-тримуватиме в заданих межах напругу на вихідній шині системи), отримаємо:

$$
k_{U_{\text {onn }}}^{0}=\frac{U_{o n m_{0}}^{5 \Phi}}{U_{o n m_{0}}^{\Gamma}} \approx \frac{U_{5 \Phi}}{U_{o n m_{0}}^{\Gamma}}=\frac{U_{H}+\Delta U_{5 \Phi}}{U_{o n m_{0}}^{\Gamma}},
$$

де $\Delta \mathrm{U}_{\text {БФ }}$ - падіння напруги на діодному блоці і в комутаційних ланцюгах (зазвичай задається при конкретній розробці). 
Вважаючи

$$
k_{I_{\text {onm }}}^{0} \approx k_{I_{K 3}} \approx k_{I}, k_{U_{\text {onm }}}^{0} \approx k_{U_{K 3}} \approx k_{U}
$$

i 3 огляду на залежності (12) i (14), можна визначити масштабні коефіцієнти у виразах (14) i далі розрахувати ВАХ БФ на базі виразу (8).

Висновки. Представлений в роботі метод обліку схемних втрат для розрахунку характеристик ФП і БФ є точним i дозволяє, базуючись на відносно простій методиці, отримати характеристики груп ФП і панелей БФ для будь-яких матеріалів ФП ( $\mathrm{Si}, \mathrm{GaAs}$, та ін.). Експериментальне отримання залежностей $\mathrm{U}_{\mathrm{xx}}$, $\mathrm{I}_{\mathrm{opt},} \mathrm{U}_{\mathrm{opt},} \mathrm{I}_{\mathrm{\kappa} 3}$ також не представляє значних труднощів i прийнятно на будь-якому відповідному експериментальному обладнанні.

1. Гаевский А.Ю. Определение параметров фотоэлектрических модулей на основе точного решения уравнения для ВАХ. Відновлювана енергетика. 2012. № 4. С. 32-39.

2. Безручко К.В., Белан Н.В., Белов Д.Г. и др. Солнечные энергосистемы космических аппаратов. Физическое и математическое моделирование. под ред. акад. НАН Украины Конюхова С.Н. Харьков. Гос. аэрокосм. ун-т «Харьк. авиац. ин-т». 2000.515 с.

3. Фаренбрух А., Бьюб Р. Солнечные элементы: теория и эксперимент. пер. с англ. под ред. M.М. Колтуна. М. Энергоатомиздат. 1987. 280 с.

4. Justus Simiyu, Elijah Ayieta, and Nicodemus Odero A Fast and Accurate Analytical Method for Parameter Determination of a Photovoltaic System Based on Manufacturer's Data. Hindawi Journal of Renewable Energy Volume 2020. Article ID 7580279. 18 p. [Електронний ресурc]. URL: https://doi.org/10.1155/2020/7580279

5. Коваль О.С., Тиванов М.С. Определение параметров солнечного элемента из его световой вольтамперной характеристики. Вестник БГУ. Сер. 1. 2012. № 2. С.39-44.

6. Базилевский А.Б., Лукьяненко М.В. Моделирование вольт-амперных характеристик солнечных батарей. Вестник Сибирского государственного аеро- космического университета имени академика М.Ф. Решетнева. Авиационная и космическая техника. C.63-66.

\section{REFERENCES}

1. Gaevskij A.Yu. Opredelenie parametrov fotoelektricheskikh module na osnove tochnogo resheniya uravneniya dlya VAKH. [Determination of parameters of photovoltaic modules based on the exact solution of the equation for volt-ampere characteristics]. Vidnovluvana energetika. 2012. No. 4. Pp.32-39. [in Russian].

2. Bezruchko K.V., Belan N.V., Belov D.G. i dr. Solnechnye energosistemy kosmicheskikh apparatov fizicheskoe i matematicheskoe modelirovanie. [Solar power systems of space equipment. Physical and mathematical modeling]. pod red. akad NAN Ukrainy Konyukhova S.N. Kharkov. Gos. aerokosm. un-t. Khark. aviacz. in-t. 2000.515 p. [in Russian].

3. Farenbrukh A., Byub R. Solnechnye elementy teoriya i eksperiment. [Solar cells: theory and experiment]. per. s angl. pod. red. M.M. Kkoltuna. M. Energoatomizdat. 1987. 280 p. [in Russian].

4. Justus Simiyu, Elijah Ayieta and Nicodemus Odero A Fast and Accurate Analytical Method for Parameter Determination of a Photovoltaic System Based on Manufacturers Data. Hindawi Journal of Renewable Energy Volume 2020. Article ID 7580279. 18 p. [Electronic resource]. URL: https://doi.org/10.1155/2020/7580279. [in English].

5. Koval O.S., Tivanov M.S. Opredelenie parametrov solnechnogo elementa iz ego svetovoy voltampernoy harakteristiki. [Determination of solar cell parameters from its light current-voltage characteristic]. Vestnik BGU. Ser. 1. 2012. No 2. Pp. 39-44. [in Russian].

6. Bazilevskiy A.B., Lukyanenko M.V. Modelirovanie volt-ampernyih harakteristik solnechnyih batarey. [Modeling the volt-ampere characteristics of solar cells]. Vestnik Sibirskogo gosudarstvennogo aerokosmicheskogo universiteta imeni akademika M. F. Reshetneva. Aviatsionnaya i kosmicheskaya tehnika. Pp.63-66. [in Russian]. 